\title{
HUBUNGAN PENGETAHUAN DENGAN PERILAKU PENCEGAHAN COVID-19 PADA ANAK USIA SEKOLAH DI KOTA JAKARTA SELATAN
}

\author{
Ressa Andriyani Utami, Ria Efkelin Mose, Martini, Ary Rahmaningsih \\ Sekolah Tinggi IImu Kesehatan RS Husada, Jakarta Pusat, DKI Jakarta, Indonesia
}

\begin{abstract}
Abstrak
Latar Belakang. Anak usia sekolah yang merupakan generasi penerus termasuk kelompok yang rentan terhadap Covid-19, kasus anak terkonfirmasi positif Covid-19 di Indonesia masih sangat tinggi sekitar 7,2\%.

Tujuan Penelitian. Mengetahui hubungan antara pengetahuan dengan perilaku pencegahan Covid 19 pada anak usia sekolah di Kota Jakarta Selatan.

Subjek dan Metode. Penelitian ini menggunakan metode analitik observasional dengan desain korelasional. Subyek penelitian ini adalah anak sekolah dasar kelas 4 sampai 6 , sampel diambil menggunakan metode cluster random sampling. Analisis data menggunakan Korelasi Pearson.

Hasil Penelitian. Mayoritas responden memiliki pengetahuan yang baik yaitu sebanyak $58 \%$ dan mayoritas responden memiliki perilaku yang kurang baik dalam pencegahan Covid-19 yaitu sebanyak $78 \%$. Terdapat hubungan antara pengetahuan dengan perilaku pencegahan Covid-19 pada anak usia sekolah $(p=0,001)$.

Kesimpulan. Terdapat hubungan antara pengetahuan dengan perilaku pencegahan covid 19 pada anak usia sekolah di Kota Jakarta Selatan.
\end{abstract}

Kata kunci: covid-19, pengetahuan, perilaku pencegahan pada anak usia sekolah

\section{CORRELATION OF KNOWLEDGE WITH PREVENTION BEHAVIOR ON COVID-19 IN SCHOOL AGE CHILDREN IN SOUTH JAKARTA}

\begin{abstract}
Background. School-age children who are the next generation are among the groups that are vulnerable to Covid-19, the cases of children confirmed positive for Covid-19 in Indonesia are still very high at around $7.2 \%$.

The Aim of The Study. Knowing the relationship between knowledge and Covid 19 prevention behavior in school-age children in South Jakarta.

Subjects and Methods. This study used an observational analytic method with a correlational design. The subjects of this study were elementary school children in grades 4 to 6, the sample was taken using the cluster random sampling method. Data analysis using Pearson Correlation.

Results. The majority of respondents have good knowledge, which is $58 \%$ and the majority of respondents have poor behavior in preventing Covid-19, which is as much as $78 \%$. There is a relationship between knowledge and Covid-19 prevention behavior in school-age children $(p=0.001)$.

Conclusion. There is a relationship between knowledge and Covid-19 prevention behavior in school-age children in South Jakarta.
\end{abstract}

Keywords: covid-19, knowledge, prevention behavior in school age children

Korespondensi: Ressa Andriyani Utami, Sekolah Tinggi Ilmu Kesehatan RS Husada, Jalan Mangga Besar Raya 137-139, Jakarta Pusat, DKI Jakarta. 11730.

Email: ressa.andriyani.utami@gmail.com 
LATAR BELAKANG

Pandemi Covid-19 terjadi pada lebih dari 114 negara yang terjadi mulai akhir tahun 2019. WHO menyatakan bahwa virus Covid-19 merupakan Public Health Emergencies International Concern (PHEIC). Covid-19 merupakan suatu penyakit yang timbul akibat corona virus jenis baru dengan masa inkubasi 1-14 hari. Gejala yang timbul mirip gejala flu biasa seperti demam tinggi, batuk dan pilek. Namun apabila penderita tidak menghiraukan penyakitnya dan tidak memperbaiki sistem imun maka akan masuk ke dalam gejala yang lebih parah seperti sesak dan kesulitan bernapas (Sposato \& Scalese, 2020). Kasus Covid-19 di Indonesia per 20 September 2020 mencapai 60.828 kasus atau $25,3 \%$, dan ini tertinggi di Indonesia. Kota Jakarta Selatan termasuk kawasan zona merah, kasus per tanggal 8 Agustus 2020 mencapai 1011 kasus terkonfirmasi positif (Satgas Covid19, 2020).

Covid-19 ini bisa menjangkiti semua orang pada berbagai tingkat usia termasuk anak usia sekolah (Wilke, Howard \& Pop, 2020). Laporan dari China, AS dan Italia menunjukkan bahwa Covid-19 menyebabkan penyakit dengan berbagai derajat pada anak-anak dan orang dewasa. Namun, data kasus pada anak-anak yang kurang representatif dalam semua kasus, terutama yang menyangkut kejadian parah dan fatal. Hanya 4.933 anak / remaja berusia 0 hingga 17 tahun ditemukan positif Covid-19 di Italia hingga 23 Juni 2020. Faktanya, hanya $2,1 \%$ dari mereka yang dirawat di rumah sakit $(0,043 \%$ dari semua rawat inap) dengan hanya 4 kasus kematian. Studi epidemiologi terbaru juga menegaskan bahwa anak-anak/ remaja cenderung tidak dilakukan swab test dibandingkan orang dewasa. Hal ini kemungkinan terjadi karena insiden yang lebih rendah (Sposato \& Scalese, 2020).
Ikatan Dokter Anak Indonesia melakukan upaya deteksi kasus Covid-19 pada anak yang dilakukan sampai dengan tanggal 18 Mei 2020 didapatkan data jumlah kasus Covid19 pada anak yaitu Pasien Dalam Pemantauan (PDP) sebanyak 3.324 kasus, sejumlah 129 anak berstatus PDP meninggal dunia, sejumlah 584 kasus anak terkonfirmasi positif Covid-19, dan 14 anak meninggal akibat Covid-19 (IDAI, 2020). Jadi kasus anak terkonfirmasi positif Covid-19 ada sekitar 7,2\% (Satgas Covid-19, 2020).

Anak usia sekolah merupakan kelompok yang rentan terhadap kondisi penyakit menular seperti Covid-19 karena kelompok usia ini masih memiliki kemampuan yang terbatas dalam mengelola kebiasaan hidup bersih dan sehat. Kelompok usia ini masih tergantung pada orang tua baik dalam hal kebersihan, penyediaan makanan yang sehat dan bergizi maupun pengambilan keputusan lainnya terkait masalah kesehatan. Disisi lain kelompok usia ini juga merupakan sumber daya manusia yang penting bagi penerus bangsa, jika kelompok usia ini tidak diperhatikan kualitas pendidikan dan kesehatannya maka bangsa Indonesia akan kehilangan generasinya (Sulastri, Purna, \& Suyasa, 2014). Salah satu bentuk upaya yang dilakukan pemerintah agar kasus Covid-19 tidak banyak terjadi pada kelompok usia ini adalah dengan menjalankan Study From Home (SFH) sehingga meminimalisir kontak dengan banyak orang secara masif (Wiresti, 2020).

Pencegahan penularan Covid-19 pada anak usia sekolah sangat penting dilakukan mengingat dampak yang akan terjadi sangat fatal. Berbagai bentuk upaya pencegahan yang dapat dilakukan adalah dengan cara mengedukasi anak mengenai penggunaan masker, tidak melakukan kontak fisik 
dengan orang lain, selalu menjaga jarak dengan orang lain minimal 2 meter, selalu mencuci tangan, mengkonsumsi makanan yang sehat dan seimbang, melakukan aktivitas fisik dengan berolahraga teratur, berjemur untuk mendapatkan vitamin D (Utami, Mose, \& Martini, 2020). Peningkatan pengetahuan mengenai pencegahan Covid-19 sangat penting dilakukan agar anak usia sekolah mampu mematuhi protokol kesehatan yang ada sehingga bisa meningkatkan derajat kesehatan diri (Erlin, Putra, \& Hendra, 2020).

Penelitian terkait yang pernah dilakukan diantaranya adalah hubungan tingkat pengetahuan dengan perilaku anak sekolah tentang hidup bersih dan sehat di sekolah dasar negeri wilayah Puskesmas Selemadeg Timur II menunjukkan bahwa ada hubungan yang signifikan dengan nilai probabilitas 0,000 (sig < 0,05) (Sulastri et al., 2014). Namun penelitian tersebut bukan terkait Covid-19 tetapi lebih umum. Penelitian lain yang dilakukan adalah peningkatan pengetahuan siswa dalam pencegahan penularan Covid-19 dengan memberikan materi tentang pencegahan penularan Covid-19 dan didapatkan hasil terdapat peningkatan pengetahuan dari $100 \%$ berpengetahuan rendah menjadi $75 \%$ berpengetahuan tinggi (Erlin, et al., 2020). Perbedaan penelitian ini dengan penelitian sebelumnya adalah variabel dan tempat penelitian.

\section{TUJUAN PENELITIAN}

Mengetahui hubungan pengetahuan dengan perilaku pencegahan Covid19 pada anak usia sekolah di Kota Jakarta Selatan.

\section{METODE}

Penelitian ini menggunakan metode observasional analitik dengan desain korelasional dengan pendekatan cross sectional. Penelitian ini menggunakan kuesioner yang disebarkan melalui google form yang dikirim kepada orang tua siswa dan diisi oleh responden. Data dianalisis menggunakan uji korelasi Pearson.

\section{SUBJEK}

Penelitian ini dilakukan pada 5 sekolah dasar di Kota Jakarta Selatan yang dipilih secara acak. Jumlah sampel sebanyak 100 siswa yang diambil dari masing-masing sekolah 20 orang dari kelas 4,5 dan 6.

\section{HASIL}

Karakteristik responden dalam penelitian ini didapatkan data:

Tabel 1.

Distribusi Frekuensi Karakteristik Responden

\begin{tabular}{lcc}
\hline Karakteristik & $\mathrm{n}$ & $\%$ \\
\hline Usia & & \\
9 & 19 & 19 \\
10 & 22 & 22 \\
11 & 26 & 26 \\
12 & 24 & 24 \\
13 & 9 & 9 \\
Jenis Kelamin & & \\
Laki-laki & 48 & 48 \\
Perempuan & 52 & 52 \\
\hline
\end{tabular}

Berdasarkan Tabel 1 tersebut didapatkan data bahwa mayoritas responden berusia 11 tahun, yaitu sebanyak $26 \%$ dan mayoritas responden berjenis kelamin perempuan yaitu sebesar $52 \%$. 
Tabel 2.

Distribusi Frekuensi Tingkat

Pengetahuan dan Perilaku Pencegahan Covid-19

\begin{tabular}{lcc}
\hline Variabel & $f$ & $\%$ \\
\hline Tk. Pengetahuan: & & \\
Baik & 58 & 58 \\
Kurang baik & 42 & 42 \\
Perilaku Pencegahan & & \\
Covid-19: & & \\
Baik & 22 & 22 \\
Kurang baik & 78 & 78 \\
\hline
\end{tabular}

Berdasarkan Tabel 2 tersebut didapatkan data mayoritas responden memiliki pengetahuan yang baik yaitu sebanyak $58 \%$ dan mayoritas responden memiliki perilaku yang kurang baik dalam pencegahan Covid-19 yaitu sebanyak $78 \%$.

Tabel 3. Hasil Analisis Hubungan Pengetahuan dengan Perilaku Pencegahan Covid-19

\begin{tabular}{lccc}
\hline \multirow{2}{*}{ Variabel } & \multicolumn{3}{c}{ Perilaku } \\
\cline { 2 - 4 } & Baik & $\begin{array}{c}\text { Kurang } \\
\text { baik }\end{array}$ & $p$ \\
\hline Pengetahuan: & & & \\
Baik & 21 & 37 & 0,001 \\
Kurang baik & 1 & 41 & \\
\hline
\end{tabular}

Hasil tabulasi silang antara tingkat pengetahuan dengan perilaku pencegahan Covid-19 dari 100 responden didapatkan data bahwa responden yang memiliki pengetahuan baik dan perilaku baik sebanyak $21 \%$, pengetahuan baik dan perilaku kurang baik sebanyak $37 \%$, pengetahuan kurang baik dan perilaku baik sebanyak $1 \%$, serta pengetahuan kurang baik dan perilaku kurang baik sebanyak $41 \%$. Hasil analisis Korelasi Pearson didapatkan nilai $p=0,000$ sehingga didapatkan kesimpulan bahwa terdapat hubungan antara pengetahuan dengan perilaku pencegahan Covid-19 pada anak usia sekolah.

\section{PEMBAHASAN}

Berdasarkan hasil analisis univariat didapatkan data bahwa mayoritas responden berusia 11 tahun, yaitu sebanyak $26 \%$ dan mayoritas responden berjenis kelamin perempuan yaitu sebesar $52 \%$. Responden pada studi yang dilakukan oleh Li, et. al (2020) tidak sama dengan penelitian ini dimana mayoritas responden penelitian berjenis kelamin laki-laki sebanyak $63,8 \%$ dan hasil penelitian menunjukkan bahwa tidak ada perbedaan signifikan yang ditemukan di proporsi laki-laki dan perempuan juga tidak berbeda nyata antara kedua kelompok $(61,4 \%$ vs. $66,1 \%, P=0,599)$.

Analisis univariat lainnya diperoleh data mayoritas responden memiliki pengetahuan yang baik yaitu sebanyak $58 \%$ dan mayoritas responden memiliki perilaku yang kurang baik dalam pencegahan Covid-19 yaitu sebanyak $78 \%$. Hasil analisis bivariat diperoleh data nilai $p=0,001$ sehingga didapatkan kesimpulan bahwa terdapat hubungan antara pengetahuan dengan perilaku pencegahan Covid19 pada anak usia sekolah. Pengetahuan yang diteliti adalah pengetahuan mengenai manfaat penggunaan masker, cara penggunaan masker yang benar, cara mencuci tangan yang benar, menjaga diri dengan tidak banyak berkatifitas di luar rumah dan selalu menjaga jarak dengan orang lain, konsumsi makanan yang dapat meningkatkan sistem imun dan berolahraga untuk menjaga kesehatan. Perilaku pencegahan yang diteliti adalah mengenai perilaku responden akan protokol kesehatan seperti penggunaan masker yang benar, tidak bermain ke luar rumah, selalu mencuci tangan menggunakan air mengalir 
dan sabun, menjaga jarak dengan orang lain, mengkonsumsi makanan sehat dan seimbang, melakukan aktivitas fisik atau olahraga.

Studi lain menunjukkan bahwa di DKI Jakarta 83\% responden memiliki pengetahuan yang baik mengenai pencegahan Covid-19 dan 70,3\% responden memiliki keterampilan yang baik (Utami et al., 2020). Hal ini menunjukkan bahwa pengetahuan yang baik tidak selalu diikuti perilaku yang baik. Akan tetapi perilaku yang baik hampir selalu karena seseorang memiliki pengetahuan yang baik. Oleh karena itu sangat penting dalam menumbuhkan pengetahuan pencegahan Covid-19 agar dapat membentuk perilaku pencegahan Covid-19 yang baik. Upaya-upaya tersebut perlu dilakukan oleh berbagai pihak dan digawangi dengan penerapan kebijakankebijakan yang konsisten.

Banyak faktor yang dapat menyebabkan terjadi Covid-19 pada anak diantaranya adalah nutrisi yang tidak memadai, ruang hidup yang sempit, dan kebersihan yang buruk. Nutrisi yang buruk dapat menyebabkan gangguan sistem kekebalan. Tempat tinggal yang penuh sesak membuat jarak sosial tidak teratur dan dapat membuat penularan virus lebih mungkin terjadi (Butler \& Barrientos, 2020). Faktor pemberian nutrisi yang baik harus tetap ditekankan kepada keluarga selaku caregiver di masa pandemik ini karena sistem imun bisa terbantuk dengan baik apabila seseorang mendapat asupan gizi yang baik. Keluarga tetap harus mengupayakan mendapatkan sumber makanan yang bergizi walaupun di masa pandemik terdapat keterbatasan dalam mencari sumber makanan yang sehat karena selain mencegah terjadinya Covid-19 juga nutrisi yang baik mencegah permasalahan gizi yang lain seperti gizi kurang dan stunting (Utami Setiawan \& Fitriyani, 2019).

Sebuah studi menyatakan bahwa Covid-19 menunjukkan perjalanan klinis yang lebih ringan pada anakanak dibandingkan pada orang dewasa. Persentase yang secara signifikan lebih rendah dari anakanak berkembang menjadi parah atau penyakit kritis dan kematian. Anak-anak mungkin hadir gejala infeksi virus non-spesifik yang menunjukkan pentingnya diagnosis banding yang akurat dengan tipikal kondisi klinis pediatrik seperti saluran pernapasan bagian atasinfeksi, demam yang tidak diketahui asalnya, pneumonia virus atau bakteri, bronkiolitis, gastroenteritis dan serangan asma (De Luca et al., 2020). Pada masa pandemik ini sesungguhnya masyarakat Indonesia tidak hanya melawan Covid-19 tetapi juga menahan peningkatan kasus lain yang sering terjadi pada anak-anak (Utami, 2017).

Perlu dilakukan edukasi yang tepat pada kelompok anak usia sekolah agar memiliki pengetahuan, sikap dan perilaku yang baik dalam mencegah masalah kesehatan. Salah satu bentuk edukasi mengenai Covid-19 dapat dilakukan menggunakan media video animasi, karena media symbolic modeling dalam bentuk audio dan visual terbukti dapat meningkatkan pengetahuan, sikap dan keterampilan siswa. Hal ini sejalan dengan penelitian yang telah dilakukan yang menunjukkan bahwa terdapat perubahan yang bermakna pada pengetahuan, sikap dan keterampilan sebelum dan sesudah diberikan intervensi edukasi menggunakan metode symbolic modeling ( $p \quad<0,05) \quad$ (Utami, Setiawan, \& Fitriyani, 2019).

Peningkatan pengetahuan yang dilakukan dengan cara penyebarluasan informasi terkait kesehatan adalah tindakan 
pemerintah yang paling umum (Wilke et al., 2020). Format dan isi informasi bervariasi, dari pesan seputar virus itu sendiri, petunjuk cuci tangan dan kebersihan, hingga penguncian dan tindakan lainnya. Pemerintah telah menghimbau tindakan jarak sosial dan penguncian untuk mencegah penyebaran virus. Namun sejauh ini pemerintah belum memfokuskan bentuk-bentuk edukasi khusus kepada kelompok anak usia sekolah. Metode ini juga akan lebih efektif dilakukan dengan menggunakan pendekatan keluarga karena yang paling sering mendampingi anak semasa pandemik di rumah adalah keluarga (Utami, Setiawan, \& Fitriyani, 2018).Tugas mendidik anak baik itu balita, anak prasekolah, anak usia sekolah maupun sampai jenjang pendidikan tinggi dalam keluarga tetap menjadi kewajiban orang tua. Apalagi di masa pandemik global seperti yang terjadi saat ini (Rohita, 2020). Peran orang tua dalam mendidik dan memberikan edukasi kesehatan tentang pencegahan Covid-19 sangat penting dilakukan karena orang tua adalah ujung tombak perlindungan kesehatan bagi seluruh anggota keluarga. Bentuk upaya yang dilakukan diantaranya bisa dengan mengajarkan fun handwashing melalui video, kegiatan menyanyi dan mewarnai (Rahmawati, Utomo \& Ahsanah, 2020).

Kebijakan pemerintah saat ini meniadakan kegiatan pembelajaran di sekolah tetapi mengalihkan segala kegiatan pembelajaran di rumah merupakan kebijakan terbaik saat ini demi menyelamatkan anak usia sekolah yang merupakan generasi penerus bangsa. Hal ini dikarenakan mengingat karakteristik anak usia sekolah dari segi kognitif ada berada tahap kognitif operasional konkrit pada masa ini sedah dibangun logika bagaimana kerja virus sehingga harus menerapkan budaya mencuci tangan, memakai masker, menjaga jarak, dan lain sebagainya. Pada fase anak usia sekolah juga sedang berada pada tahap membangun hidup sehat terhadap diri sendiri dan lingkungan sehingga posisi ini anak belum dipastikan bisa menjaga kesehatan personal dan lingkungan karena masih perlu diawasi ketat oleh orang dewasa yang berada di sekitarnya. Sama halnya dengan kajian yang dilakukan di Almajrie, Nigeria yang menunjukkan bahwa pemerintah perlu mempertimbangkan dengan matang anak usia sekolah yang bersekolah di asrama/pondok perlu dipulangkan atau tidak harus meninjau berbagai keadaan karena sifat Covid-19 yang ditularkan melalui udara menjadikannya faktor risiko penyebaran penyakit karena orang yang tidak terinfeksi dapat terinfeksi dari droplet akibat bersin dan batuk oleh mereka yang terinfeksi (Akintunde, Chen \& Di, 2020).

Penularan Covid-19 dapat terjadi melalui droplet dan aerosol sehingga penting membentuk perilaku anak untuk menghindari transmisi virus ke dalam tubuhnya. Edukasi penggunaan masker pada anak usia sekolah tidak bisa dengan mudah dilakukan. Orang tua seringkali kesulitan meminta anak menggunakan masker dikarenakan anak tidak terbiasa dengan adaptasi kebiasaan baru. Akan tetapi sebuah penelitian yang menunjukkan bahwa penularan Covid-19 selain melalui droplet dan aerosol juga ternyata virus masih ditemukan pada feses pasien beberapa minggu setelah diagnosis. Hal ini menunjukkan bahwa rute transmisi fekal oral dapat terjadi pada bayi, balita dan anak (Xiao et al., 2020). Dengan adanya hasil riset seperti ini menunjukkan bahwa menjadi hal yang sangat penting untuk mencuci tangan pada waktu-waktu tertentu seperti sebelum makan, setelah buang air 
besar, setelah dari luar, dan lain sebagainya. Suatu tinjauan literatur juga mengkaji bahwa mencuci tangan menggunakan sabun di air mengalir lebih efektif karena mekanisme kerja molekul sabun yang dapat merusak membran virus Covid-19 dan bakteri lainnya (Nakoe, S Lalu, \& Mohamad, 2020).

\section{KESIMPULAN}

Terdapat hubungan yang bermakna antara pengetahuan dengan perilaku pencegahan Covid-19 pada anak usia sekolah $(p=0,001)$.

\section{SARAN}

Masyarakat terutama pihak keluarga dan sekolah perlu memberikan edukasi yang baik dan benar mengenai pencegahan penularan Covid-19 karena dengan pengetahuan yang baik maka akan meningkatkan perilaku pencegahan yang baik.

Penelitian selanjutnya dapat dilakukan terkait metode edukasi yang tepat bagi anak usia sekolah sehingga dapat membentuk perilaku sesuai dengan protokol kesehatan.

\section{DAFTAR PUSTAKA}

Akintunde, T. Y., Chen, S., \& Di, Q. 2020. Public health implication of displacement of Almajiri children in specific states of Northern Nigeria amidst COVID-19 pandemic. Ethics, Medicine and Public Health, 14, 100544.

https://doi.org/10.1016/j.jemep. 2020.100544

Butler, M. J., \& Barrientos, R. M. 2020. The impact of nutrition on COVID-19 susceptibility and long-term consequences. Brain, Behavior, and Immunity, 87 (April), 53-54. https://doi.org/10.1016/j.bbi.202 0.04.040
De Luca, C. D., Esposito, E., Cristiani, L., Mancino, E., Nenna, R., Cortis, E., \& Midulla, F. 2020. Covid-19 in children: A brief overview after three months experience. Paediatric Respiratory Reviews, 35, 9-14. https://doi.org/10.1016/j.prrv.20 20.05.006

Erlin, F., Putra, I. D., \& Hendra, D. 2020. Peningkatan

Pengetahuan Siswa dalam Pencegahan Penularan Covid19, 4 (4), 7-9.

Li, Y., Wang, H., Wang, F., Du, H., Liu, X., Chen, P., Lu, X. 2020. Comparison of hospitalized patients with pneumonia caused by COVID-19 and influenza $A$ in children under 5 years. International Journal of Infectious Diseases, 98, 80-83. https://doi.org/10.1016/j.ijid.202 0.06 .026

Nakoe, R., S Lalu, N. A., \& Mohamad, Y. A. 2020. Perbedaan Efektivitas HandSanitizer Dengan Cuci Tangan Menggunakan Sabun Sebagai Bentuk Pencegahan Covid-19. Jambura Journal of Health Sciences and Research, 2 (2), 65-70.

https://doi.org/10.35971/jjhsr.v2i 2.6563

Rahmawati, N. V., Utomo, D. T. P., \& Ahsanah, F. 2020. Fun Hanwashing Sebagai Upaya Pencegahan Covid-19 Pada Anak Usia Dini. Jurnal Masyarakat Mandiri, 4 (2), 218.

Rohita. 2020. Pengenalan Covid-19 pada Anak Usia Prasekolah: Analisis pada Pelaksanaan Peran Orangtua di Rumah. Jurnal Obsesi: Jurnal Pendidikan Anak Usia Dini, 5 (1), 315-319. https://doi.org/10.31004/obsesi. v5i1.528. 
Satgas Covid-19. 2020. Komite Penanganan Covid-19 dan Pemulihan Ekonomi Nasional. Kemenkes RI, Jakarta.

Sposato, B., \& Scalese, M. 2020. Why do children seem to be more protected against COVID19? A hypothesis. Medical Hypotheses, 143 (May), 110151.

https://doi.org/10.1016/j.mehy.2 020.110151

Sulastri, K., Purna, I. N., \& Suyasa, I. N. G. 2014. Hubungan Tingkat Pengetahuan Dengan Perilaku Anak Sekolah Tentang Hidup Bersih Dan Sehat Di Sekolah Dasar Negeri Wilayah Puskesmas Selemadeg Timur li. Journal of Environmental Health, 4, 99-106. Retrieved from http://www.poltekkesdenpasar.ac.id/files/JURNAL KESEHATAN LINGKUNGAN/Ketut Sulastri1, I Nyoman Purna2, NyomanGede Suyasa3.pdf

Utami, R. A. 2017. Hubungan Pemberian Nutrisi dengan Kejadian Stunting pada Balita di Kelurahan Karang Anyar. Jurnal Kesehatan Holistic, 1(2), 22-31. https://doi.org/https://doi.org/10. 33377/jkh.v1i2.36

Utami, R. A., Mose, R. E., \& Martini, M. 2020. Pengetahuan, Sikap dan Keterampilan Masyarakat dalam Pencegahan Covid-19 di DKI Jakarta. Jurnal Kesehatan Holistic, 4(2), 68-77. https://doi.org/10.33377/jkh.v4i2. 85

Utami, R. A., Setiawan, A., \& Fitriyani, P. 2018. Penerapan Symbolic Modeling melalui Pendekatan Keluarga, 2, 30-40.
Utami, R. A., Setiawan, A.,\& Fitriyani, P. 2019. Identifying causal risk factors for stunting in children under five years of age in South Jakarta, Indonesia. Enfermeria Clinica, 29, 606-611. https://doi.org/10.1016/j.enfcli.2 019.04 .093

Utami, R. A., Setiawan, A., \& Fitriyani, P. 2019. Pengaruh Aplikasi Model "Simbol Andi" Terhadap Pengetahuan, Sikap Dan Keterampilan Anak Usia Sekolah Dengan Risiko Cedera di Kota Depok. Jurnal Keperawatan Indonesia, 22 (3), 182-190. https://doi.org/10.7454/jki.v22i3. 592

Wilke, N. G., Howard, A. H., \& Pop, D. 2020. Data-informed recommendations for services providers working with vulnerable children and families during the COVID-19 pandemic. Child Abuse and Neglect, (June), 104642. https://doi.org/10.1016/j.chiabu. 2020.104642

Wiresti, R. D. 2020. Analisis Dampak Work From Home pada Anak Usia Dini di Masa Pandemi Covid-19. Jurnal Obsesi : Jurnal Pendidikan Anak Usia Dini, 5 (1), 641653 https://doi.org/10.31004/obsesi. v5i1.563

Xiao, F., Tang, M., Zheng, X., Liu, Y., Li, X., \& Shan, H. 2020. Evidence for gastrointestinal infection of SARS-CoV-2. Gastroenterology. https://doi.org/10.1053/j.gastro. 2020.02.055 